\title{
CLONING OF PUTATIVE ureG GENES FROM Glomus intraradices AND UREASE ACTIVITIES IN TOBACCO ARBUSCULAR MYCORRHIZAL ROOTS
}

\author{
Daniele Takahashi; Renata Fava Ditt; Marcio R. Lambais* \\ USP/ESALQ - Depto. de Ciência do Solo, C.P. 09 - 13418-900 - Piracicaba, SP - Brasil. \\ *Corresponding author <mlambais@esalq.usp.br>
}

\begin{abstract}
Even though the major benefit of arbuscular mycorrhizae is the increased uptake of phosphate from the soil solution and translocation to the plant, changes in the activity of enzymes involved in nitrogen $(\mathrm{N})$ metabolism have been detected in mycorrhizal roots. Using differential display of reverse-transcripts of tobacco roots not-inoculated or inoculated with Glomus intraradices (Gi), we have cloned two partial cDNAs (NtGi2 and NtGi3). The presence of a conserved CobW/HypB/ UreG domain and phylogenetic analyses suggest that $\mathrm{NtGi} 2$ and NtGi3 encode isoforms of urease accessory protein $\mathrm{G}$ (ureG) highly similar to ure G from fungi. The steady state levels of the putative ure $\mathrm{G}$ transcripts were shown to be higher in roots colonized by $\mathrm{Gi}$, as compared to non-mycorrhizal controls. Urease activities were also determined in tobacco roots inoculated with Glomus clarum (Gc) or Gi and grown in substrate containing 50,100 or $150 \mathrm{mg} \mathrm{N} \mathrm{kg}^{-1}$ in the form of ammonium sulfate (NAMS) or urea (N-URE). Urease activities were shown to be induced in mycorrhizal roots fertilized with $100 \mathrm{mg} \mathrm{N}-\mathrm{AMS} \mathrm{kg}^{-1}$. In Gc-colonized roots fertilized with N-URE, induction of urease activities was observed at the lowest $\mathrm{N}$ concentration. In contrast, at the highest N-URE concentration, suppression of urease activities was observed in Gc and Gi-colonized roots, as compared to non-mycorrhizal controls. Urease activities in roots were modulated by soil $\mathrm{N}$ availability and source, and arbuscular mycorrhizal fungal inoculation.
\end{abstract}

Key words: Nicotiana tabacum, DDRT-PCR, arbuscular mycorrhiza, urea, ammonium sulfate, nitrogen

\section{CLONAGEM DE GENES ureG PUTATIVOS DE Glomus intraradices E ATIVIDADES DE UREASE EM RAÍZES MICORRÍZICAS ARBUSCULARES DE TABACO}

\begin{abstract}
RESUMO: Muito embora o maior benefício de micorrizas arbusculares seja o incremento na absorção de fosfato da solução do solo e translocação para a planta, alterações nas atividades de enzimas envolvidas no metabolismo de nitrogênio $(\mathrm{N})$ têm sido detectadas em raízes micorrizadas. Usando "differential display of reverse-transcripts" de raízes de tabaco não-inoculadas ou inoculadas com Glomus intraradices (Gi), dois cDNAs parciais (NtGi2 e NtGi3) foram clonados. A presença de um domínio CobW/HypB/UreG conservado e a análise filogenética sugerem que NtGi2 e NtGi3 codificam isoformas de proteínas acessórias da urease $\mathrm{G}$ (ureG) altamente similares a ureG de fungos. Os níveis de transcritos dos genes ure $G$ putativos foram mais elevados em raízes colonizadas por $\mathrm{Gi}$, em relação ao controle não-micorrizado. As atividades de urease foram determinadas em raízes de tabaco inoculadas com Glomus clarum (Gc) ou Gi e cultivadas em substrato contendo 50,100 ou $150 \mathrm{mg} \mathrm{N} \mathrm{kg}^{-1}$, na forma de sulfato de amônio (N-AMS) ou uréia (N-URE). As atividades de ureases foram induzidas em raízes micorrizadas cultivadas com 100 mg N-AMS $\mathrm{kg}^{-1}$. Em raízes colonizadas por Gc e cultivadas com N-URE, a indução das atividades de urease foi observada na concentração mais baixa de N. Em contraste, na concentração mais elevada de N-URE, supressão das atividades de urease em raízes colonizadas por Gc e Gi, em relação aos controles não-micorrizados, foi observada. As atividades de urease nas raízes foram moduladas pela disponibilidade e fonte de $\mathrm{N}$ no solo, e pela inoculação com fungos micorrízicos arbusculares.

Palavras-chave: Nicotiana tabacum, DDRT-PCR, micorriza arbuscular, uréia, sulfato de amônio, nitrogênio
\end{abstract}

\section{INTRODUCTION}

Increased uptake of phosphate $(\mathrm{P})$ from the soil solution and translocation to the plants is the ma- jor benefit of arbuscular mycorrhiza (AM) (Smith et al., 1985; Azcón et al., 1992). Nevertheless, there is evidence that arbuscular mycorrhizal fungi (AMF) may also increase the uptake of nitrogen $(\mathrm{N})$ from the soil 
and translocation to the host plant (Ames et al., 1983; Smith et al., 1985; Azcón et al., 1992; Cliquet \& Stewart, 1993; Bago et al., 1996; Johansen et al., 1996). In addition, AMF have been strongly implicated in $\mathrm{N}$ transfer between different plants interconnected by the same mycelium (He et al., 2003).

The mechanisms controlling $\mathrm{N}$ transfer from the fungus to the plant are not totally understood. According to the model proposed by Bago et al. (2001), $\mathrm{N}$ is taken up by the AMF as $\mathrm{NO}_{3}^{-}$or $\mathrm{NH}_{4}^{+}$. The assimilated $\mathrm{N}$ is translocated along the coenocytic hyphae in vacuoles as arginine, and, in the intraradical mycelia, arginine is hydrolized by arginase to urea. The resulting urea is then hydrolyzed to $\mathrm{NH}_{3}$ and $\mathrm{CO}_{2}$ through the activity of a fungal urease, and $\mathrm{NH}_{4}^{+}$is transferred to the host plant. Corroborating this model, it has been shown that arginine is transported intact from the extraradical to the intraradical mycelium, where it is broken down and the resulting $\mathrm{NH}_{4}^{+}$transferred to the plant (Govindarajulu et al., 2005). Furthermore, the levels of expression of fungal genes highly homologous to ornithine aminotransferase, urease accessory protein and an ammonium transporter in the intraradical mycelium of $G$. intraradices are higher than in the extraradical mycelium (Govindarajulu et al., 2005). These data suggest that fungal urease activities are important for the completion of the $\mathrm{N}$ translocation process between the symbionts in AM. In plants and bacteria, the functionality of ureases is dependent on the activity of urease accessory protein G (UreG) (Polacco et al., 1999; Freyermuth et al., 2000). However, whether ure $G$ expression in AM is related to urease activity is not known.

In this study, using differential display of reverse transcripts (DDRT)-PCR, two partial cDNAs encoding proteins highly similar to ure $G$ genes from fungi, plant and bacteria have been cloned, and the activity of urease in mycorrhizal roots evaluated under different $\mathrm{N}$ sources and concentrations.

\section{MATERIAL AND METHODS}

\section{Cloning and gene expression experiments}

Plant material, inoculation and growth - Tobacco (Nicotiana tabacum cv. Petit Havana) seedlings were grown for six weeks in a sterilized mixture of sand and vermiculite $(2: 1, \mathrm{v}: \mathrm{v})$ and transplanted to pots containing $3 \mathrm{~kg}$ of the same substrate. All pots received $60 \mathrm{mg}$ of $\mathrm{P}$ as $\mathrm{KH}_{2} \mathrm{PO}_{4}, 180 \mathrm{mg}$ of $\mathrm{K}$ as $\mathrm{KCl}, 120 \mathrm{mg}$ of $\mathrm{Ca}$ as $\mathrm{CaCl}_{2}, 60 \mathrm{mg}$ of $\mathrm{Mg}$ as $\mathrm{MgSO}_{4} \cdot 7 \mathrm{H}_{2} \mathrm{O}, 1 \mathrm{~mL}$ Fe-EDTA solution and $1 \mathrm{~mL}$ of micronutrients solution (Sarruge, 1975). At transplanting, seedlings were inoculated with soil containing a mixture of spores, hyphae and roots of Brachiaria decumbens colonized by Glomus intraradices Schenck \& Smith. Soil containing $B$. decumbens roots not colonized by AMF was used for the inoculation of non-mycorrhizal control treatments. To the growth substrate it was added 100 $\mathrm{mg} \mathrm{N} \mathrm{kg}{ }^{-1}$ substrate as ammonium sulfate (N-AMS). Plants were grown under greenhouse conditions at $28^{\circ} \mathrm{C}$, and soil humidity was maintained at $70 \%$ of the maximum water holding capacity by addition of destiled water. Plants were harvested eight weeks after transplanting. Root subsamples were either fixed in FAA $3.7 \%$ formaldehyde, $50 \%$ ethanol, $5 \%$ glacial acetic acid in water) for evaluation of intraradical fungal colonization or stored at $-80^{\circ} \mathrm{C}$ for RNA extraction.

Intraradical fungal colonization - Root subsamples fixed in FAA were stained with trypan-blue and the intraradical fungal colonization was evaluated using the intersection method in Petri dishes, under a stereoscopic microscope (Phillips \& Hayman, 1970; Giovannetti \& Mosse, 1980). Intraradical fungal colonization was determined as the percentage of root length colonized by AMF.

Differential display of reverse transcripts-PCR Total RNA was isolated from tobacco roots colonized by $G$. intraradices (intraradical colonization rates of 45 $\pm 3 \%$, average of ten replicates \pm SEM) by the phenol:sodium dodecyl sulfate (SDS) method as described by Lambais \& Mehdy (1993). Total RNA was treated with RNAse free-DNAse I (Boehringer Mannheim, Mannheim, Germany) in $20 \mathrm{mM}$ Tris- $\mathrm{HCl}$ (pH 8.4), $50 \mathrm{mM} \mathrm{KCl}, 20 \mathrm{mM} \mathrm{MgCl}$, containing 0.4

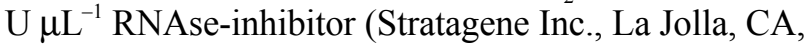
USA) for $90 \mathrm{~min}$ at $37^{\circ} \mathrm{C}$. Two $\mu \mathrm{g}$ of DNAse I-treated total RNA were used for first strand cDNA synthesis with M-MuLV reverse transcriptase (Stratagene Inc., La Jolla, CA, USA) and AP2 (5'-T $\left.{ }_{13} \mathrm{VG}^{3} 3^{\prime}\right)$ primer (Liang \& Pardee, 1992). The reaction was incubated for $60 \mathrm{~min}$ at $37^{\circ} \mathrm{C}$, and then at $95^{\circ} \mathrm{C}$ for five min. Amplification of the cDNA was performed using $1 \mu \mathrm{L}$ of the reverse transcription reaction, in $1 \mathrm{X}$ PCR buffer containing $2 \mathrm{mM} \mathrm{MgCl}, 200 \mathrm{mM}$ dNTPs, $0.5 \mathrm{U}$ Taq DNA polymerase and $0.2 \mu \mathrm{M}$ of $\mathrm{B} 03$ (5'ACTTCGACAA-3') primer. The cycling conditions consisted of an initial denaturation at $94^{\circ} \mathrm{C}$ for one min, 35 cycles of denaturation at $94^{\circ} \mathrm{C}$ for one min, anneling at $42^{\circ} \mathrm{C}$ for one min and extension at $72^{\circ} \mathrm{C}$ for two min, and a final extension at $72^{\circ} \mathrm{C}$ for five min. Amplicons were separated by electrophoresis on $2 \%$ agarose-TBE gels, and banding pattern analysed by densitometry using Personal Densitometer SI and the software ImageQuant (GE Healthcare, São Paulo, Brazil), after staining with ethidium bromide (Sambrook et al., 1989). 
Cloning and sequencing - Differentially displayed cDNAs were eluted from agarose gels, ligated into pCR-Script SK $(+)$ vector (Stratagene, La Jolla, CA, USA) and transformed into $E$. coli DH5 competent cells. Transformants were selected and recombinant plasmids extracted by alkaline lysis from overnight grown liquid cultures (Sambrook et al., 1989). Two cDNA inserts, named NtGi2 and NtGi3, were sequenced using Big Dye Terminator (Applied Biosystems, Foster City, CA, USA) and either T3-forward or M13-reverse primers. Deduced amino acid sequences of $\mathrm{NtGi} 2$ and NtGi3 were compared to sequences in public databases using BLAST (Altschul et al., 1997).

Phylogenetic analyses - The deduced amino acid sequences (121 amino acid residues) of NtGi2, NtGi3 and the most similar sequences of fungi, plant and bacteria from public databases were aligned using ClustalW of MEGA 4 (Tanura et al., 2007). Phylogenetic bootstrap consensus tree (1000 replicates) was determined using the MEGA 4 (Tanura et al., 2007).

RNA Blot analyses - Total RNA (30 $\mu \mathrm{g})$ from tobacco mycorrhizal and non-mycorrhizal roots (eight weeks after inoculation) was transferred to Hybond $\mathrm{N}^{+}$membranes (GE Healthcare, São Paulo, Brazil). Clones NtGi2 and NtGi3 were labeled with digoxigenin-11-dUTP using the DIG DNA Labeling and Detection kit (Boehringer Mannheim, Mannheim, Germany), according to the manufacturer's instructions. Membranes were pre-hybridized for four h at $50^{\circ} \mathrm{C}$ in $5 \mathrm{X} \mathrm{SSC}, 50 \mathrm{mM}$ sodium phosphate ( $\mathrm{pH} 7.2$ ), $50 \%$ formamide, $2 \%$ nonfat dried milk, 7\% SDS and $0.1 \%$ laurylsarcosyl. Hybridization was performed overnight at $50^{\circ} \mathrm{C}$ in $5 \mathrm{X} \mathrm{SSC}, 50 \mathrm{mM}$ sodium phosphate (pH 7.2), $50 \%$ formamide, $2 \%$ nonfat dried milk, 7\% SDS and 0.1\% laurylsarcosyl containing DIG-11-dUTP labelled cDNA probe. Membranes were washed twice in $2 \mathrm{X} \mathrm{SSC}, 0.1 \%$ SDS for five min at room temperature and twice in $0.5 \mathrm{X} \mathrm{SSC}, 0.1 \%$ SDS for $15 \mathrm{~min}$ at $65^{\circ} \mathrm{C}$. Detection was performed using anti-DIG alkaline phosphatase conjugate and Lumigen-PPD, using the DIG DNA Labeling and Detection kit (Boehringer Mannheim, Mannheim, Germany), according to the manufacturer's instructions. Autoradiograms were analyzed by densitometry, using Personal Densitometer SI and the software ImageQuant.

\section{Enzyme activity experiments}

Plant material, inoculation and growth - Tobacco seedlings were grown as described above, except that at transplanting seedlings were inoculated with soil containing a mixture of spores, hyphae and roots of Brachiaria decumbens colonized by Glomus clarum Nicol. \& Schenck or Glomus intraradices Schenck \&
Smith. Additionally, to the growth substrate it was added either 50,100 or $150 \mathrm{mg} \mathrm{N} \mathrm{kg}^{-1}$ substrate as ammonium sulfate (N-AMS) or urea (N-URE). Plants were harvested eight weeks after transplanting, and shoots were separated from the root systems, washed with distilled water and dried at $70^{\circ} \mathrm{C}$ to constant mass, in order to determine the shoot dry matter (SDM). Root subsamples were either washed with distilled water and dried at $70^{\circ} \mathrm{C}$ to constant mass, in order to determine root dry matter (RDM), or fixed in FAA (3.7\% formaldehyde, $50 \%$ ethanol, $5 \%$ glacial acetic acid in water) for evaluation of intraradical fungal colonization.

Nitrogen concentration in leaves - Dried leaves were ground to a fine powder and $\mathrm{N}$ concentration determined using the Kjeldhal method (Malavolta et al., 1997).

Urease specific activities in roots - Root tissue was ground to a fine powder in liquid nitrogen and homogenized in $100 \mathrm{mM}$ phosphate buffer $(\mathrm{pH} 7.5), 1 \mathrm{mM}$ ethylenediaminetetraacetic acid (EDTA), $1 \mathrm{mM}$ phenylmethanesulfonyl fluoride, $0.5 \%$ polyvinylpolypyrrolidone. Homogenates were centrifuged at $15,000 \mathrm{~g}$ for $20 \mathrm{~min}$ at $4^{\circ} \mathrm{C}$ (Lambais et al., 2003). Protein concentration was determined using the Bradford protein detection reagent (BioRad, Hercules, CA, USA) and bovine serum albumin as standard, according to the manufacturer's instructions. Urease specific activity was determined using $500 \mu \mathrm{L}$ of protein extract in $500 \mu \mathrm{L} 0.1 \mathrm{M}$ Tris-malate buffer containing $1 \mathrm{mM}$ EDTA (pH 7.0) and $50 \mathrm{mM}$ urea, according to Miksch et al. (1994). Samples were incubated for 60 min at $37^{\circ} \mathrm{C}$, and the concentration of released $\mathrm{NH}_{3}$ determined spectrophotometrically using the Sigma-Ammonium kit (Sigma Chemical Co., St. Louis, MO, USA). Urease specific activities were expressed as $\mathrm{nmol} \mathrm{NH}_{3}$ released $\mathrm{h}^{-1} \mathrm{mg}^{-1}$ protein.

Experimental design and data analyses - The first experiment was performed using two treatments with ten replicates per treatment. The second experiment was performed using a factorial arrangement comprised of three inoculation treatments, two $\mathrm{N}$ sources and three $\mathrm{N}$ concentrations, with four replicates per treatment. Analyses of variance (ANOVA) were performed using SYSTAT 8.0 software (SPSS Inc., Chicago, IL, USA). Means were compared using the Tukey's test $(p<0.05)$.

\section{RESULTS}

Characterization of the NtGi2 and NtGi3 cDNA clones Tobacco roots used for DDRT-PCR experiments showed intraradical colonization rates by $G$. 
intraradices of $45 \pm 3 \%$ (mean $\pm \mathrm{SEM}$ ), whereas notinoculated controls showed no intraradical colonization. Two cDNAs with preferential accumulation in mycorrhizal roots named $\mathrm{NtGi} 2$ (850 bp) and NtGi3 (800 bp) were isolated from DDRT gels for further analyses (Figure 1A). Dot blot hybridization experiments, using the NtGi2 cDNA clone as probe showed that the expression of this gene was 3.1-fold higher in mycorrhizal roots than in non-mycorrhizal control roots (Figure 1B). When the NtGi3 cDNA was used as a probe, no hybridization signal was detected with RNA from non-mycorrhizal roots, under our experimental conditions (Figure 1B).

The deduced amino acid sequences of the NtGi2 and NtGi3 cDNA clones showed high levels of similarity to the deduced amino acid sequences of putative ure $G$ genes of fungi, plants and bacteria (Table 1). Both NtGi2 and NtGi3 clones harbor a conserved CobW/HypB/UreG domain, with E-values of $1.210^{-10}$ and $3.710^{-47}$, respectively (Figure 2). NtGi3 was highly related to the $G$. intraradices UAP clone described by Govindarajulu et al. (2005). Based on the phylogenetic analyses of the putative UreG proteins from several organisms, $\mathrm{NtGi} 2$ and $\mathrm{NtGi} 3$ were shown to be more related to fungal than to plant proteins (Figure 3). Inclusion of $G$. intraradices UAP clone in the phylogenetic analyses was not possible, since the sequence available showed only a partial overlap (59 deduced amino acid residues) with $\mathrm{NtGi} 3$ and no overlap with NtGi2 sequences.

\section{Enzyme activity experiments}

Plant biomass - Regardless of the N source and concentration, differences between the SDM of mycor- rhizal and non-mycorrhizal plants were not observed (Tukey's test, $p>0.05$; Figure 4), indicating that the presence of G. clarum or G. intraradices did not affect shoot biomass production. However, non-mycorrhizal plants cultivated with the highest concentration

A

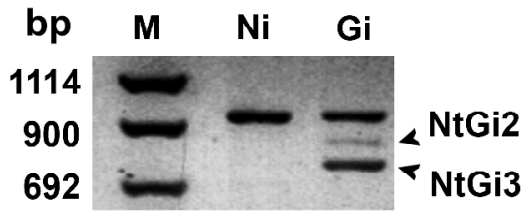

B

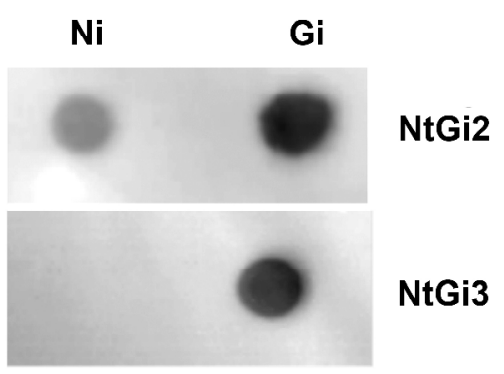

Figure 1 - Differential expression of putative urease accessory protein $\mathrm{G}$ genes in tobacco roots not-inoculated $(\mathrm{Ni})$ or inoculated with Glomus intraradices (Gi). A, Differential display of reverse transcripts. The arrows indicate transcripts with preferential accumulation in mycorrhizal roots as compared to the nonmycorrhizal controls. NtGi2 and $\mathrm{NtGi} 3$ represent the respective cDNA clones. B, Steady state levels of $\mathrm{NtGi} 2$ and $\mathrm{NtGi} 3$ transcripts. $\mathrm{NtGi} 2$ or $\mathrm{NtGi} 3$ cDNAs were used as hybridization probes on equal amounts of total root RNA.

Table 1 - Similarities between the deduced amino acid sequences of NtGi2 and NtGi3 and those of selected fungal, plant and bacterial putative $u r e G$ genes.

\begin{tabular}{|c|c|c|c|c|c|c|c|}
\hline \multirow{2}{*}{ Accession } & \multirow{2}{*}{ Organism } & \multicolumn{3}{|c|}{$\mathrm{NtGi} 2$} & \multicolumn{3}{|c|}{ NtGi3 } \\
\hline & & E-value & $\%$ Identity & $\%$ Similarity & E-value & $\%$ Identity & $\%$ Similarity \\
\hline AAW41177 & Cryptococcus neoformans & $510^{-65}$ & 75 & 86 & $410^{-78}$ & 78 & 89 \\
\hline CAB91432 & Neurospora crassa & $410^{-59}$ & 75 & 85 & $110^{-76}$ & 77 & 87 \\
\hline XP 755621 & Aspergillus fumigatus & $110^{-59}$ & 70 & 80 & $910^{-75}$ & 76 & 86 \\
\hline AAW69327 & Magnaporthea grisea & $510^{-56}$ & 70 & 78 & $210^{-74}$ & 77 & 84 \\
\hline NP 1800994 & Arabidopsis thaliana & $310^{-55}$ & 71 & 82 & $810^{-73}$ & 75 & 86 \\
\hline AAD44338 & Glycine $\max$ & $310^{-54}$ & 71 & 80 & $210^{-72}$ & 75 & 85 \\
\hline CAC 33000 & Solanum tuberosum & $110^{-54}$ & 70 & 81 & $410^{-72}$ & 74 & 86 \\
\hline AAT77406 & Oryza sativa & $110^{-52}$ & 68 & 81 & $610^{-71}$ & 74 & 86 \\
\hline ZP 00107996 & Nostoc punctiforme & $410^{-35}$ & 59 & 79 & $310^{-55}$ & 66 & 78 \\
\hline ABA24233 & Anabaena variabilis & $710^{-35}$ & 61 & 77 & $310^{-55}$ & 68 & 80 \\
\hline AAZ32981 & $\begin{array}{l}\text { Pseudomonas syringae pv. } \\
\text { phaseolicola }\end{array}$ & $310^{-35}$ & 64 & 80 & $510^{-53}$ & 66 & 81 \\
\hline ZP 01109669 & Alteromonas macleodii & $410^{-35}$ & 59 & 77 & $110^{-53}$ & 64 & 80 \\
\hline
\end{tabular}



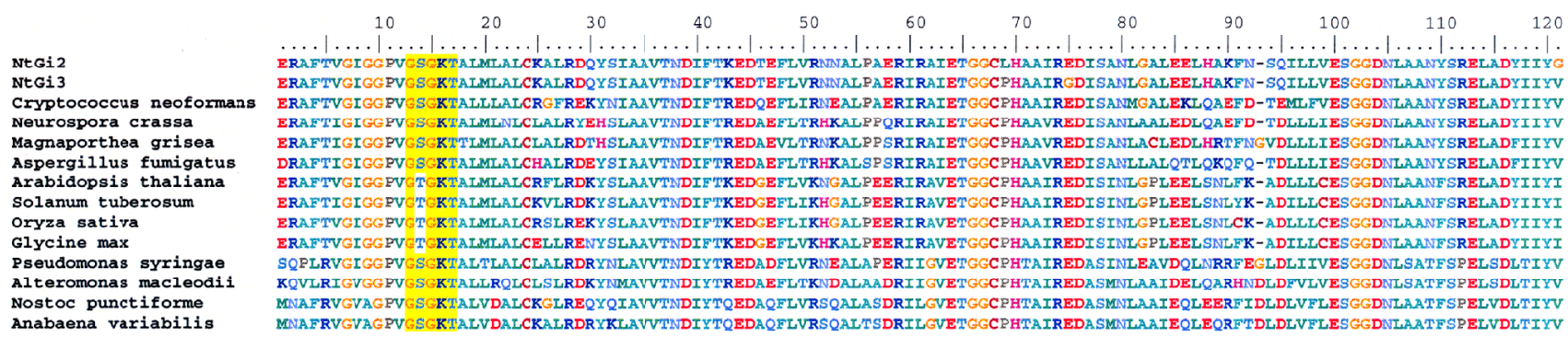

Figure 2 - Alignment of the CobW/HypB/UreG conserved domain of putative urease accessory protein G from several organisms. Accession numbers are: NtGi2 (DQ499469), NtGi3 (DQ499470), C. neoformans (AAW41177), N. crassa (CAB91432), A. fumigatus (XP755621), M. grisea (AAW69327), A. thaliana (NP180994), S. tuberosum (CAC33000), O. sativa japonica group (AAT77406), G. max (AAD44338), P. syringae pv. phaseolicola (AAZ32981), A. macleodii (ZP01109669), N. punctiforme (ZP00107996), A variabilis (ABA24233). The conserved domain is highlighted in yellow.

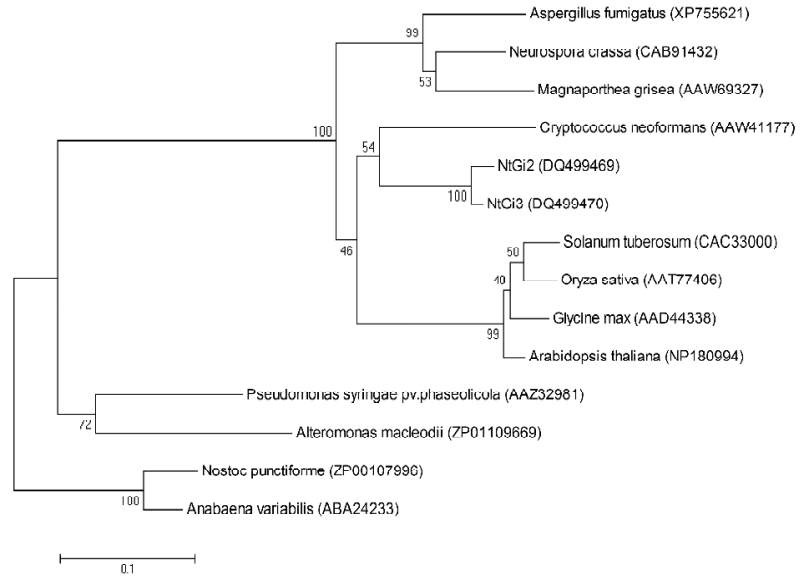

Figure 3 - Phylogenetic relationships between putative urease accessory protein $\mathrm{G}(\mathrm{UreG})$ of selected organisms based on the deduced amino acid sequences of their genes. Bootstrap values $(n=1,000$ replicates $) \geq 40 \%$ are reported as percentages at the respective node. Scale bar represents number of changes per amino acid position.

of N-AMS produced $26 \%$ less shoot biomass than plants cultivated with the same concentration of $\mathrm{N}$ URE ( $p<0.05$; Figure 4). Higher SDM was observed in the treatments with higher $\mathrm{N}$ concentrations, regardless of the $\mathrm{N}$ source, as compared to the controls with $50 \mathrm{mg} \mathrm{N} \mathrm{kg}^{-1}$ substrate (Tukey's test, $p>0.05$; Figure 4).

RDM did not differ in plants inoculated with G. clarum or G. intraradices, as compared to non-mycorrhizal controls (Tukey's test, $p>0.05$; Figure 4). Increases in RDM were observed in plants grown with 100 and $150 \mathrm{mg}$ N-AMS or N-URE per kg of substrate, as compared to plants grown with $50 \mathrm{mg} \mathrm{N}$ AMS or N-URE per kg of substrate (Tukey's test, $p<0.05)$. In general, mycorrhizal plants cultivated with $100 \mathrm{mg}$ N-AMS per $\mathrm{kg}$ of substrate produced less root biomass than plants cultivated with $100 \mathrm{mg}$ N-URE per kg of substrate (Tukey's test, $p<0.05$ ).
Intraradical fungal colonization - Intraradical fungal colonization was higher in plants inoculated with G. clarum, as compared to plants inoculated with $G$. intraradices (Table 2), and was affected by the interaction of the factors "N concentration" and "Inoculation treatment" ( $\mathrm{F}$ test, $p<0.05$ ). The percentage of the root length showing intraradical colonization by $G$. clarum in plants cultivated with $150 \mathrm{mg} \mathrm{N} \mathrm{kg}^{-1}$ substrate was approximately 2 -fold higher than in plants cultivated with $50 \mathrm{mg} \mathrm{N} \mathrm{kg}^{-1}$ substrate, independent of the $\mathrm{N}$ source. The intraradical colonization by $G$. intraradices was not affected by $\mathrm{N}$ concentration, regardless of the $\mathrm{N}$ source used (Tukey's test, $p>0.05$ ).

The intraradical colonization by G. clarum was higher in plants cultivated with $150 \mathrm{mg} \mathrm{N} \mathrm{kg}^{-1}$, as compared to plants cultivated with $50 \mathrm{mg} \mathrm{N} \mathrm{kg}^{-1}$ substrate, independent of the $\mathrm{N}$ source (Tukey's test, $p<0.05$ ). The intraradical colonization by $G$. intraradices was not affected by $\mathrm{N}$ concentration, in plants cultivated with $\mathrm{N}$-AMS or N-URE (F test, $p>0.05$; Table 2 ). The intraradical colonization by $G$. clarum, but not by $G$. intraradices, was positively correlated with urease specific activities in roots (Pearson, $p<0.05$ ).

Nitrogen concentration in leaves - Nitrogen concentrations in leaves were higher in plants grown under high $\mathrm{N}$ concentration, as compared to low $\mathrm{N}$ concentration (Tukey's test, $p<0.05$; Table 3). Regardless of the $\mathrm{N}$ source used, the differences between $\mathrm{N}$ concentrations in the leaves of $G$. intraradices and $G$. clarum colonized plants, and non-mycorrhizal controls were not significant ( $\mathrm{F}$ test, $p<0.05$ ).

Urease specific activities in roots - Urease specific activities in roots were affected by the interaction between the factors "Inoculation treatment", "N source" and "N concentration" ( $\mathrm{F}$ test, $p<0.05$; Figure 5). Differences in urease specific activities in the roots of mycorrhizal plants cultivated with N-AMS, as compared to non-mycorrhizal controls, were observed only 
at $100 \mathrm{mg} \mathrm{N}-\mathrm{AMS} \mathrm{kg}^{-1}$ substrate (Tukey's test's test, $p<0.05$ ). In plants cultivated with $100 \mathrm{mg}$ N-AMS $\mathrm{kg}^{-1}$ substrate, an increase in urease specific activities, approximately 1.5 and 1.9-fold, in roots colonized by G. clarum and G. intraradices, as compared to the nonmycorrhizal control, was observed (Figure 5A).

Table 2 - Intraradical mycorrhizal colonization in Nicotiana tabacum cultivated with different concentrations of N, supplied either as urea (URE) or ammonium sulfate (AMS).

\begin{tabular}{|c|c|c|c|}
\hline $\mathrm{N}$ source & $\mathrm{N}$ concentration & G. clarum & G. intraradices \\
\hline \multirow{4}{*}{ URE } & $\mathrm{mg} \mathrm{kg}^{-1}$ & \multicolumn{2}{|c|}{ - } \\
\hline & 50 & $29.0 \mathrm{Ba}$ & $6.1 \mathrm{Ab}$ \\
\hline & 100 & $42.3 \mathrm{ABa}$ & $4.8 \mathrm{Aab}$ \\
\hline & 150 & $66.8 \mathrm{Aa}$ & $10.0 \mathrm{Ab}$ \\
\hline \multirow{3}{*}{ AMS } & 50 & $38.7 \mathrm{Ba}$ & $21.8 \mathrm{Ab}$ \\
\hline & 100 & $56.6 \mathrm{ABa}$ & $23.5 \mathrm{Ab}$ \\
\hline & 150 & $79.5 \mathrm{Aa}$ & $6.3 \mathrm{Ab}$ \\
\hline
\end{tabular}

The data are the means of four replicates. Means followed by the same letter do not differ (Tukey's test, $p<0.05$ ). Capital letters are used to compare the means within the columns, and $\mathrm{N}$ source. Small letters are used to compare means within rows, and $\mathrm{N}$ source and concentrations.

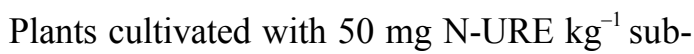
strate and colonized by $G$. clarum showed a significant increase (3-fold) in urease specific activities in roots, as compared to the non-mycorrhizal control ( $p$ $<0.05$; Figure 5B). In roots colonized by $G$. intraradices and cultivated with 50 and $100 \mathrm{mg} \mathrm{N}-\mathrm{URE}$ $\mathrm{kg}^{-1}$ substrate, changes in urease specific activities were not observed, when compared to the non-mycorrhizal controls. In plants cultivated with $150 \mathrm{mg} \mathrm{N}$ URE $\mathrm{kg}^{-1}$ substrate, urease specific activities in roots colonized by $G$. clarum or $G$. intraradices were approximately 3 -fold lower than in roots of non-mycorrhizal controls $(p<0.05)$. In non-mycorrhizal roots, urease specific activities were higher in plants culti-

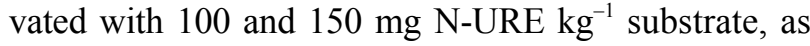
compared to plants cultivated with $50 \mathrm{mg} \mathrm{N}-\mathrm{URE} \mathrm{kg}^{-1}$ substrate.

Using Pearson's correlation analyses, a highly significant correlation $(p=0.018)$ between urease specific activities in mycorrhizal roots and total $\mathrm{N}$ in leaves were observed for plants cultivated with N-URE, independent of the $\mathrm{N}$ concentration (data not shown). For plants cultivated with N-AMS such correlation was not significant $(p>0.05)$.

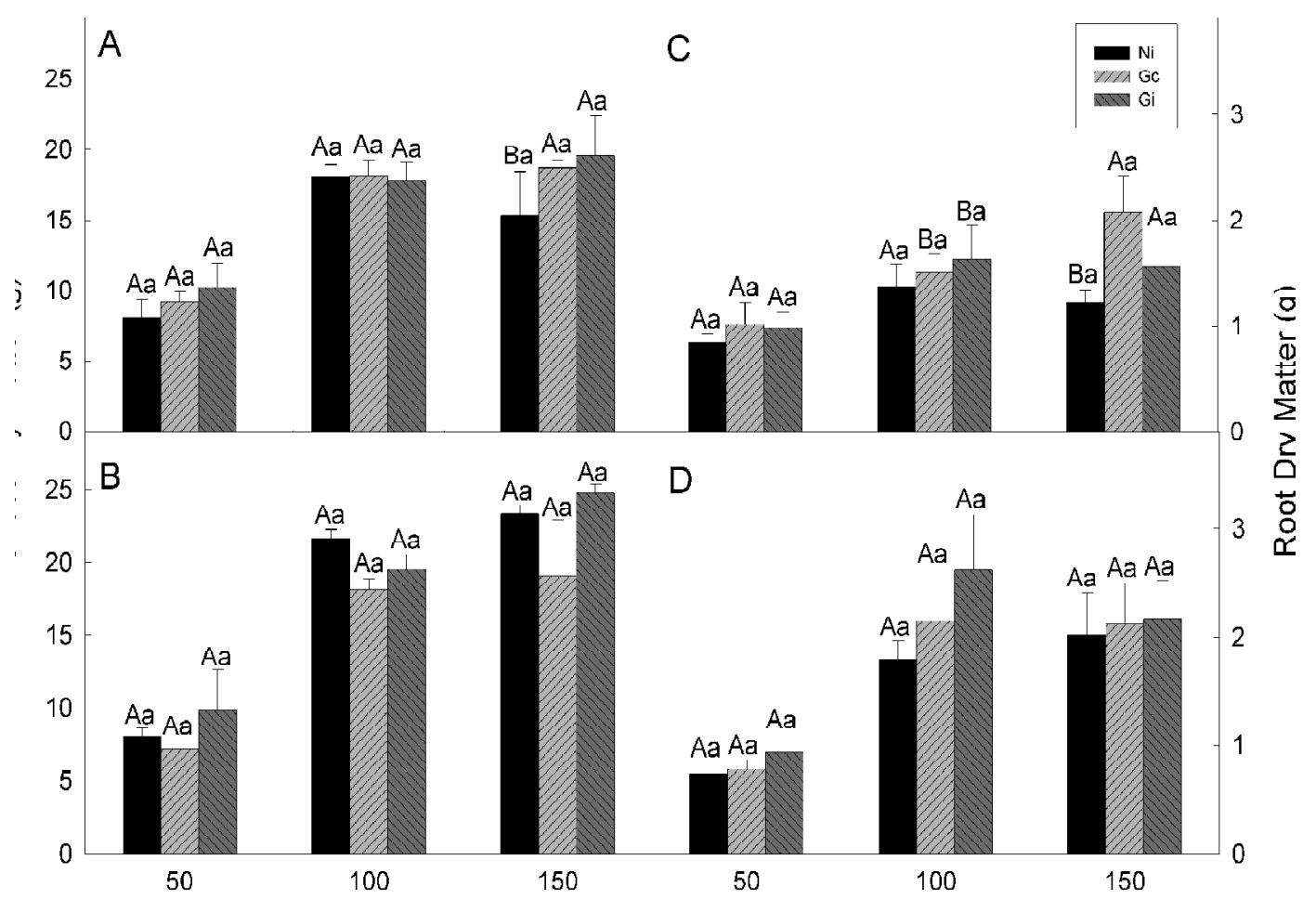

Figure 4 - Shoot (A, B) and root (C, D) dry matter of mycorrhizal and non-mycorrhizal Nicotiana tabacum cultivated with ammonium sulfate $(A, C)$ or urea $(B, D)$ at different concentrations. The data are the means of four replicates \pm SE. Ni, not-inoculated; Gc, inoculated with Glomus clarum; Gi, inoculated with Glomus intraradices. Means of SDM or RDM followed by the same letter do not differ (Tukey's test, $p<0.05$ ). Capital letters are used to compare the means of the inoculation treatments, within $\mathrm{N}$ source and concentration. Small letters are used to compare the means of the $\mathrm{N}$ source, within $\mathrm{N}$ concentration and inoculation treatment. 
Table 3 - Concentration of N in leaves of Nicotiana tabacum not-inoculated (Ni) or inoculated with G. clarum (Gc) or G. intraradices (Gi), and cultivated with different $\mathrm{N}$ concentrations, applied as urea (URE) or ammonium sulfate (AMS).

\begin{tabular}{lccrc}
\hline \multirow{2}{*}{ N source } & N concentration & \multicolumn{3}{c}{ Inoculation treatment } \\
\cline { 2 - 4 } & $\mathrm{mg} \mathrm{kg}$ & $\mathrm{Ni}$ & $\mathrm{Gc}$ & $\mathrm{Gi}$ \\
\hline \multirow{2}{*}{$\mathrm{URE}$} & 50 & $10.2 \pm 1.3 \mathrm{Ab}$ & $9.0 \pm 0.6 \mathrm{Ab}$ & $9.1 \pm 1.2 \mathrm{Ab}$ \\
& 100 & $9.6 \pm 0.7 \mathrm{Ab}$ & $10.7 \pm 0.6 \mathrm{Ab}$ & $11.4 \pm 0.6 \mathrm{Ab}$ \\
\hline \multirow{2}{*}{$\mathrm{AMS}$} & 150 & $14.7 \pm 1.4 \mathrm{Aa}$ & $14.3 \pm 0.7 \mathrm{Aa}$ & $13.6 \pm 0.5 \mathrm{Aa}$ \\
& 50 & $9.0 \pm 1.1 \mathrm{Ab}$ & $9.7 \pm 1.1 \mathrm{Ab}$ & $9.6 \pm 0.3 \mathrm{Ab}$ \\
\hline
\end{tabular}

The data are the means of four replicates \pm SEM. Means followed by the same letter do not differ (Tukey's test, $p<0.05$ ). Capital letters are used to compare the means within the rows, $\mathrm{N}$ source and concentration. Small letters are used to compare means within columns, $\mathrm{N}$ source and inoculation treatments.

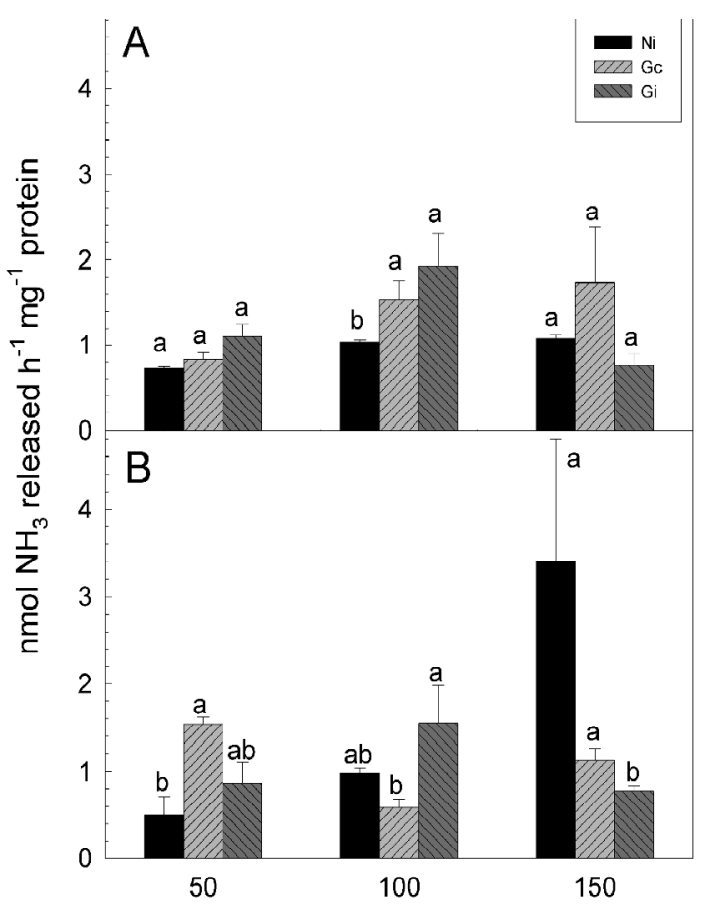

Figure 5 - Urease specific activities in mycorrhizal and nonmycorrhizal roots of Nicotiana tabacum cultivated with ammonium sulfate (A) or urea (B) at different concentrations. The data are the means of four replicates $\pm \mathrm{SE}$. Ni, not-inoculated; Gc, inoculated with Gomus clarum; Gi, inoculated with Glomus intraradices. Letters are used to compare the means of the inoculation treatments, within $\mathrm{N}$ sources and concentrations. Means with the same letter do not differ (Tukey's test, $p<0.05$ ).

\section{DISCUSSION}

Using DDRT-PCR, we have identified two partial cDNA clones whose deduced amino acids sequences were highly similar to UreG proteins from several organisms. The NtGi3 clone characterized in this work showed a high level of similarity to the urease accessory protein (UAP) gene of $G$. intraradices spores described by Govindarajulu et al. (2005), at the amino acid level. However, due to the small overlap between the deduced amino acid sequences (59 residues at the N-terminal end), no further comparisons could be made. The presence of a conserved CobW/ $\mathrm{HypB} / \mathrm{UreG}$ domain in NtGi2 and NtGi3 suggests that they encode UreG proteins. Phylogenetic analyses based on the deduced amino acid sequences of ure $G$ genes showed that $\mathrm{NtGi} 2$ and $\mathrm{NtGi} 3$ are more related to fungal UreG proteins. Thus, our data strongly suggest that both clones encode isoforms of $G$. intraradices UreG proteins. Total RNA dot blot hybridization experiments using either $\mathrm{NtGi} 2$ or $\mathrm{NtGi} 3 \mathrm{cDNA}$ clones as probes showed that $u r e G$ genes are expressed in tobacco mycorrhizal roots, and that $\mathrm{NtGi} 2$ might share high similarity to a tobacco ure $G$ gene, since hybridization signals were detected in both mycorrhizal and non-mycorrhizal roots. UreG is a chaperone responsible for nickel insertion in the active site of ureases and essential for the functionality of these enzymes (Polacco et al., 1999). Soybean mutants defective in ure $G$ are not able to synthesize functional ureases (Freyermuth et al., 2000). Furthermore, site directed mutagenesis in the conserved CobW/HypB/UreG domain of Helicobacter pylori ure G gene (Lys14 to Ala14) showed that this domain is essential for enzyme activity (Mehta et al., 2003).

In some pathogenic microorganisms, such as H. pylori and Cryptococcus neoformans, the activities of ureases are associated with their virulence and are essential for the infection of host tissues (Cox et al., 2000; McGee et al., 1999). Similarly, in mycorrhizal roots it is possible that ureases may be associated with fungal infectivity. In this work, a positive correlation 
between urease specific activities in roots and intraradical fungal colonization by the most infective fungus $(\mathrm{Gc})$ was observed. However, whether urease activities are associated with the infectivity of the fungus or with the fungal biomass in the roots remains to be determined. Alternatively, urease might be involved in the degradation of arginine and $\mathrm{N}$ transfer from the intraradical mycelium to the plant.

To determine whether urease activities in tobacco roots were modulated in mycorrhizal roots, tobacco plants were inoculated with either G. clarum or G. intraradices and grown under different $\mathrm{N}$ sources and concentrations. In plants cultivated with $100 \mathrm{mg}$ of N-AMS kg-1 substrate and inoculated with either $G$. clarum or G. intraradices, urease specific activities were induced, whereas at 50 or $150 \mathrm{mg} \mathrm{N}-\mathrm{AMS} \mathrm{kg}^{-1}$ substrate no effects of the inoculation were observed. Conversely, Cruz et al. (2007) observed that urease activities were higher in carrot roots colonized by $G$. intraradices grown in media containing either 0.1 or $5 \mathrm{mM}$ ammonium sulfate, as compared to controls without N. These data indicate that urease activities are modulated by AMF inoculation and $\mathrm{N}$ concentration in the growth substrate.

Additionally, urease specific activities in mycorrhizal roots were modulated by the $\mathrm{N}$ source in the growth substrate. Under our experimental conditions, urease specific activities were induced only in roots colonized by G. clarum at the lowest N-URE concentration. At the highest concentration of N-URE, in contrast, a suppression of urease specific activities was observed in roots colonized by G. clarum or $G$. intraradices, as compared to the non-mycorrhizal controls. These data indicate that the $\mathrm{N}$ source can also modulate urease activities in AM. However, whether there is a mechanistic relationship between urease activities in roots and symbioses development and/or effectiveness in translocating $\mathrm{N}$ to the plant is not known.

The intraradical colonization by G. clarum was higher than by $G$. intraradices, and was stimulated by higher $\mathrm{N}$ concentrations in the growth substrate, independent of the $\mathrm{N}$ source used for fertilization. In roots of Anthylis vulneraria transformed with the Riplasmid of Agrobacterium rhizogenes, root colonization by Glomus etunicatum was also stimulated at high $\mathrm{N}$ concentrations, when plants were grown at low $\mathrm{P}$ conditions (Bressan, 2001). These data suggest that $\mathrm{N}$ is an important determinant of intraradical fungal colonization.

Furthermore, the model proposed by Bago et al. (2001) and Govindarajulu et al. (2005) suggests that fungal ureases in $\mathrm{AM}$ are important for $\mathrm{N}$ translocation from the fungus to the plant. Their model pre- dicts that the $\mathrm{N}$ taken up by the fungus is transported through the mycelium as arginine, which is degraded to urea and the latter to ammonium by fungal ureases. Thus, higher urease activity in mycorrhizal roots would result in higher assimilation of $\mathrm{N}$ by the host plant and more likely higher amounts of $\mathrm{N}$ in leaves. In our study, total urease specific activities (fungal and plant) in mycorrhizal roots were only positively correlated with the total amount of $\mathrm{N}$ in leaves of plants cultivated with N-URE, suggesting that ureases may have an additional role in roots other than $\mathrm{N}$ acquisition by the plant. Alternatively, $\mathrm{N}$ transferred to the plant via hypha is only partially translocated to the shoots, or the contribution of the $\mathrm{N}$ translocated from the fungus to the plant for the total amount of $\mathrm{N}$ in the shoots of tobacco may not be significant regardless of the $\mathrm{N}$ source.

In summary, we have cloned two putative ure $G$ genes from $G$. intraradices whose transcripts were more abundant in mycorrhizal than in non-mycorrhizal roots. We also showed that the activities of ureases in tobacco roots are modulated by AMF inoculation, $\mathrm{N}$ source and concentration.

\section{ACKNOWLEDGMENTS}

This project was supported by FAPESP (São Paulo, Brazil). MRL was supported by CNPq (Brasília, Brazil), RFD by FAPESP (São Paulo, Brazil) and DT by CAPES (Brasília, Brazil). Nucleotide sequences of NtGi2 and NtGi3 have been deposited at GenBank under accession numbers DQ499469 and DQ499470, respectively.

\section{REFERENCES}

ALTSCHUL, S.F.; MADDEN, T.L.; SCHAFFER, A.A., ZHANG, J.H.; ZHANG, Z.; MILLER, W.; LIPMAN, D.J. Gapped BLAST and PSI-BLAST: a new generation of protein database search programs. Nucleic Acids Research, v.25, p.3389-3402, 1997.

AMES, R.N.; REID, C.P.P.; PORTER, L.K.; CAMBARDELLA, C. $\mathrm{N}-15$ uptake and transport by hyphae of a vesicular-arbuscular mycorrhizal fungus. Phytopathology, v.5, p.840-841, 1983.

AZCÓN, R.; GOMEZ, M.; TOBAR, R. Effects of nitrogen source on growth, nutrition, photosynthetic rate and nitrogen metabolism of mycorrhizal and phosphorus-fertilized plants of Lactuca sativa L. New Phytologist, v.121, p.227-234, 1992.

BAGO, B.; VIERHEILIG, H.; PICHE, Y.; AZCÓN-AGUILAR, C. Nitrate depletion and $\mathrm{pH}$ changes induced by the extraradical mycelium of the arbuscular mycorrhizal fungus Glomus intraradices grown in monoxenic culture. New Phytologist, v.133, p.273-280, 1996.

BAGO, B.; PFEFFER, P.; SHACHAR-HILL, Y. Could the urea cycle be translocating nitrogen in the arbuscular mycorrhizal symbiosis? New Phytologist, v.149, p.4-8, 2001.

BRESSAN, W. The interactive effect of phosphorus and nitrogen on in vitro spore germination of Glomus etunicatum Becker \& Gedermann, root growth and mycorrhizal colonization. Brazilian Journal of Microbiology, v.32, p.276-280, 2001. 
CLIQUET, J.B.; STEWART, G.R. Ammonia assimilation in Zea mays L. infected with a vesicular-arbuscular mycorrhizal fungus Glomus fasciculatum. Plant Physiology, v.101, p.865-871, 1993.

COX, G.M.; MUKHERJEE, J.; COLE, G.T.; CASADEVAL, A.; PERFECT, J.R. Urease as a virulence factor in experimental cryptococcosis. Infect Immunology, v.68, p.443-448, 2000.

CRUZ, C.; EGSGAARD, H.; TRUJILlO, C.; AMBUS, P.; REQUENA, N.; MARTINS-LOUÇÃO, M.A.; JAKOBSEN, I. Enzymatic evidence for the key role of arginine in nitrogen translocation by arbuscular mycorrhizal fungi. Plant Physiology, v.144, p.782-792, 2007.

FREYERMUTH, S.K.; BACANAMWO, M.; POLACCO, J.C. The soybean Eu3 gene encodes a Ni-binding protein necessary for urease activity. Plant Journal, v.21, p.53-60, 2000.

GIOVANNETTI, M.; MOSSE, B. An evaluation of techniques for measuring vesicular-arbuscular mycorrhizal infection in roots. New Phytologist, v.84, p.489-500, 1980.

GOVINDARAJULU, M.; PFEFFER, P.E.; JIN, H.; ABUBAKER, J.; DOUDS, D.D.; ALLEN, J.W.; BÜCKING, H,; LAMMERS, P.J.; SHACHAR-HILL, Y. Nitrogen transfer in the arbuscular mycorrhizal symbiosis. Nature, v.435, p.819-823, 2005.

HE, X.; CRITCHLEY, C.; BLEDSOE, C. Nitrogen transfer within and between plants through commom mycorrhizal networks (CMNs). Critical Reviews in Plant Science, v.22, p.531$567,2003$.

JOHANSEN, A.; FINLAY, R.D.; OLSSON, P.A. Nitrogen metabolism of external hyphae of the arbuscular mycorrhizal fungus Glomus intraradices. New Phytologist, v.133, p.705$712,1996$.

LAMBAIS, M.R.; MEHDY, M.C. Suppression of endochitinase, $\beta$ 1,3-endoglucanase, and chalcone isomerase expression in bean vesicular-arbuscular mycorrhizal roots under different soil phosphate conditions. Molecular Plant-Microbe Interactions, v.6, p.75-83, 1993.

LAMBAIS, M.R.; RÍOS-RUIZ, W.F.; ANDRADE, R.M. Antioxidant responses in bean (Phaseolus vulgaris) roots colonized by arbuscular mycorrhizal fungi. New Phytologist, v.160, p.421428,2003
LIANG, P.; PARDEE, A.B. Differential display of eukaryotic messenger RNA by means of the polymerase chain reaction. Science, v.257, p.967-971, 1992.

Malavolta, E.; VitTi, G.C.; Oliveira, A.S. Avaliação do estado nutricional das plantas: princípios e aplicações. Piracicaba: POTAFOS, 1997. 319p.

McGEE, D.J.; MAY, C.A.; GARNER, R.M.; HIMPSI, J.M.; MOBELY, H.I.T. Isolation of Helicobacter pylori genes that modulate urease activity. Journal of Bacteriology, v.181, p.2477-2484. 1999.

MEHTA, N.; BENOIT, S.; MAIER, R.J. Roles of conserved nucleotide-binding domains in accessory proteins, НypB and UreG, in the maturation of nickel-enzymes required for efficient Helicobacter pylori colonization. Microbial Pathogenesis, v.35, p.229-234, 2003.

PHILLIPS, J.M.; HAYMAN, D.S. Improved procedures for clearing roots, and staining parasitic and vesicular-arbuscular mycorrhizal fungi for rapid assessment of infection. Transactions of British Mycological Society, v.55, p.158-162, 1970.

POLACCO, J.C.; FREYERMUTH, S.K.; GERENDAS, J.; CIANZIO, S.R. Soybean genes involved in nickel insertion into urease. Journal of Experimental Botany, v.50, p.1145-1156, 1999.

SAMBROOK, J.; FRITSCH, E.F.; MANIATIS, T. Molecular cloning: a laboratory manual. New York: Cold Spring Harbor Laboratory Press, 1989. 3v. 1659p.

SARRUGE, J.R. Soluções nutritivas. Summa Phytopathologica, V.1, p.231-233, 1975.

SMITH, G.S.; CORNFORTH, I.S.; HENDERSON, H.V. Critical leaf concentrations for deficiencies of nitrogen, potassium, phosphorus, sulfur, and magnesium in perennial ryegrass. New Phytologist, v.101, p.393-409, 1985.

TANURA, K.; DUDLEY, J.; NEI, M.; KUMAR, S. MEGA 4: Molecular Evolutionary Genetics Analysis (MEGA) software version 4.0. Molecular Biology and Evolution, v.24, p.1596$1599,2007$.

Received May 18, 2007

Accepted August 25, 2008 